\title{
PENGARUH LINGKUNGAN BELAJAR TERHADAP PRESTASI BELAJAR AKUNTANSI DENGAN KECERDASAN EMOSIONAL SEBAGAI VARIABEL MODERATING
}

\section{THE EFFECT OF LEARNING ENVIRONMENT ON THE ACCOUNTING LEARNING ACHIEVEMENT WITH EMOTIONAL QUOTIENT AS MODERATING VARIABLE}

\author{
Oleh: \\ Muammar Syarif Mifthahurrachman \\ Accounting Education Department \\ syarif_acil@ rocketmail.com
}

\begin{abstract}
Abstrak
Penelitian ini dilakukan untuk mengetahui pengaruh Lingkungan Belajar terhadap Prestasi Belajar Akuntansi siswa kelas XI IPS SMA Muhammadiyah 3 Yogyakarta tahun ajaran 2013/2014. Kecerdasan Emosional digunakan sebagai variabel moderasi. Penelitian ini memiliki dua tujuan. Pertama, bertujuan untuk mengetahui pengaruh Lingkungan Belajar terhadap Prestasi Belajar Akuntansi siswa kelas XI IPS SMA Muhammadiyah 3 Yogyakarta tahun ajaran 2013/2014. Kedua, untuk mengetahui pengaruh Kecerdasan Emosional pada hubungan antara Lingkungan Belajar dan Prestasi Belajar Akuntansi siswa kelas XI IPS SMA Muhammadiyah 3 Yogyakarta tahun ajaran 2013/2014.

Penelitian ini termasuk penelitian "ex-post facto", peneliti mencoba untuk menentukan penyebab, pengaruh, dan efek dari suatu peristiwa yang telah dipelajari oleh peneliti sebelumnya. Penelitian ini bertujuan untuk mengetahui pengaruh variabel independen, Lingkungan Belajar (X1) terhadap variabel dependen, Akuntansi Prestasi Belajar (Y) melalui variabel moderating yang memperkuat hubungan antara variabel independen dan dependen yaitu Kecerdasan Emosional (X2). Karena data yang dikumpulkan dalam angka, analisis yang digunakan adalah pendekatan kuantitatif.

Berdasarkan hasil penelitian, ada bukti empiris bahwa terdapat pengaruh positif dan signifikan dari Lingkungan Belajar terhadap Prestasi Belajar Akuntansi di Kelas XI IPS SMA Muhammadiyah 3 Yogyakarta Tahun Akademik 2013/2014. Hal ini menunjukan lingkungan belajar yang baik akan berdampak positif terhadap Prestasi Belajar Akuntansi mereka. Ada juga bukti empiris yang menunjukkan bahwa ada pengaruh positif dan signifikan dari Kecerdasan emosional dalam hubungan antara Lingkungan Belajar dan Prestasi Belajar Akuntansi siswa di Kelas XI IPS SMA Muhammadiyah 3 Yogyakarta Tahun Akademik 2013/2014. Para siswa dengan Kecerdasan Emosional yang tinggi dan Lingkungan Belajar yang kondusif dapat meningkatkan Prestasi Belajar Akuntansi mereka.
\end{abstract}

Kata kunci: Lingkungan Belajar, Kecerdasan Emosional, Variabel Moderating

\section{Abstract}

This research is conducted to find the effect of learning environment on the Achievement in Accounting Learning Process gained by the XI IPS class of SMA Muhammadiyah 3 Yogyakarta, year 2013/2014. Emotional quotient is used as the moderating variable. This research has two main objectives. First, it is aimed to investigate the effect of Learning Environment on the Accounting Learning Achievement of XI IPS SMA Muhammadiyah 3 Yogyakarta academic year 2013/2014 students. Second, it is to investigate 
the influence of Emotional Quotient on the relation between the Learning Environment and Accounting Learning Achievement of XI IPS SMA Muhammadiyah 3 Yogyakarta academic year 2013/2014 students.

It is the ex post fact research, the researcher tried to define the cause, influence, and the effect of an event which had been studied by the researcher in hindsight. This research is aimed to find the influence of the independent variable, the Learning Environment $\left(X_{1}\right)$ on the dependent variable, The Accounting Learning Achievement $(Y)$ through moderating variable which strengthen the relation between the independent and dependent variables that is the Emotional Quotient $\left(X_{2}\right)$. Since the collected data is in numbers, the analysis used is quantitative approach.

Based on the research result, there is empirical evidence that there is a positive and significant effect of the Learning Environment on the Accounting Learning Achievement in XI IPS Class of SMA Muhammadiyah 3 Yogyakarta Academic Year 2013/2014. There is also empiricial evidence that there is a positive and significant effect of the Emotional Quotient on the Learning Environment and Accounting Learning Achievement in XI IPS Class of SMA Muhammadiyah 3 Yogyakarta Academic Year 2013/2014.

Keywords: Learning Environment, Emotional Quotient, Modetating Variable

\section{INTRODUCTION}

Education takes an important part in ensuring the life of the nation by being a medium for increasing and improving human resources. Through education, the students are expected to be much better in improving their potencies. The well achieved education can be seen from the result they got on their final report. Education at school is commonly run classically. It means that the students in the same grade have no difference in getting the materials as well as the teaching process, rooms, and facilities. However, the achievement on the final report shows that the difference does exist. Some of them get high grade, while the rest is either adequate or low.

The Accounting Learning Achievement similar to the level of achievement at school, in the certain period which is stated in scores or marks leaves the problems as mentioned above. In addition, the good mark is expected by the students, their parents, teachers, headmaster, and government. The school committee has always reinforced the Accounting Learning Achievement in various ways by improving the efficiency and effectiveness of teaching - learning process. The effort in improving the education's quality can be held by assessing the students' learning achievement as the direct indicator of education's quality, so it can be fulfilled along with the enhancement of students' achievement.

As an institution which runs the teaching-learning process, SMA Muhammadiyah 3 Yogyakarta has always reinforced the actualization of higher education's quality. The school's great commitment to increase it is realized in its vision, which stated, "Membentuk Peserta Didik yang Berimtaq, Cerdas, Kompetitif, dan Berjiwa Muhammadiyah."

According to the observation held, there are 25 students $(24,03 \%)$ from the total amount of 140 XI IPS SMA Muhammadiyah 3 Yogyakarta students who have not yet passed the Minimum Passing Criteria or Kriteria Ketuntasan Minimum (KKM) which is set in score 75 for Accounting's Achievement in Accounting Learning. The students have a difficulty in understanding Accounting because some of them think that in completely achieving the good marks, they 
are less supported by the school's environment.

The school environment has an influence on the learning process's success. According to Arif Rochman (2009: 195), “The education's surroundings are everything which covers the ongoing process of education." It is everything which immerses the students in having their learning activities.

The Education's Environment comes from social and non-social surroundings. Nonsocial surroundings is the physical factors, such as the place, the school's location, learning tools, learning sources, the school's buildings condition, classrooms, environmental hygiene teaching aids. On the other hand, the social factors include the students' family, their social surroundings at home and school. The authorized Education's Environments which are surely shaping the comfortable atmosphere to study, such as the availability of physical learning facilities, comfortable places to study, quiet atmosphere and harmonic relation to the social surroundings; can encourage the students to study Accounting, so it will increase their Achievement on Accounting Learning Process. On the contrary, if it did not support them, they will less courageously learn Accounting, which later could decrease their achievement.

According to the author observation's report in SMA Muhammadiyah 3 Yogyakarta, it shows that the learning environment in this place contributes less support. It is not only the factor of school's location, which is situated on the roadside, where the vehicles' noise disturbs the teaching-learning process, but also lack of teaching aids to support the students get in gaining the optimum learning process. The school's social surroundings tend to ignore the students, so it seems like there is no guidance from the society around.

Based on the author's interview while observing some students of SMA Muhammadiyah 3 Yogyakarta, it was confessed by them that their social surroundings gave less contribution to support the authorized learning atmosphere. Lack of support from their parents and friends who have low motivation in learning was the reason why they thought that their social surroundings were less conducive for them to be able to study well.

The diversity of existing inputs can be seen from intelligence (IQ) which gives a great influence on the successful teachinglearning process. Many people think that to gain the great achievement of learning, someone has to have a high Intelligence Quotient (IQ) as it is a potential provision which eases them in learning and helps them to get an optimum result.

Mc Clelland (1973) in Goleman (2000:25) mentioned that:

The high congenital academic ability, marks on the final report and the graduation's predicate would not predict how good one's performance is after working or how success is the result achieved in life. On the contrary, a set of specific skills, such as empathy, self discipline, and initiative are able to differentiate a successful person from the mediocre achievers. This factor is known as Emotional Quotient (EQ).

The perspective on Intelligence Quotient mentioned that a triumph is considered by intelligence only, but there is another perspective which stated that in achieving success, it needs a balance between emotion and cognition. Emotional Quotient determines how good a person is in use the creativities he has, including the skills. The old paradigm considered the ideal idea is that there is logic without emotion, while the new paradigm thought that the ideal condition is the compatibility between head and heart. The emotional quotient is intended to the effort to recognize, understand, and embody the emotion in the proportional portion. Another thing which is also important in 
emotional quotient is the effort to handle the emotion, so it will be beneficial for accomplishing the problem in life, especially related to the human's relation. In fact, it is sometime happened that a student who has a high intelligence quotient got the low grade.

According to Goleman (2009: 47), Intelligence Quotient (IQ) contributes only $20 \%$ to success, while the $80 \%$ is contributed by the other strength factor, such as Emotional Quotient (EQ), the ability to motivate them, handle the frustration, control the inner impulse, control the mood, give empathy, and cooperate.

The phenomena met in SMA Muhammadiyah 3 Yogyakarta when the author was having an observation are the inability of many students in controlling their emotions or being aggressive, such as being rude to others; quarrelling, being around with problematic kids, improper behaved at home and school, being stubborn, having changeable mood, being too much in speaking, mocking others a lot, and being temperamental. Within the social interaction, there are many students who pull themselves from it, such as tending to be alone, hiding themselves, giving their gloomy face and less excited, being unhappy, and depending much on something. The other problems in giving attention and thinking are there are plenty students who are incapable of well focusing their attention or at least sitting calmly. They tend to daydream mostly, act without thinking first, strictly act so they cannot focus on studying, get bad marks so often at school, and incapable to calm their mind. In fact, it is not all of the students who are able to manage their Emotional Quotient, which leads to inability to motivate and force them, so they are less focus and intent to be passive in learning process at school. This problem impacts on the less optimum of the students' effort in understanding the material given in the classroom.
The deficient learning environment can be seen from less attention of the parents in guiding the students to study at home and the atmosphere which is less conducive; this could be the barriers to gain the optimal academic achievement, including the Achievement in Accounting Subject. Even though the surroundings are not conducive, there are several things which could affect how bad or good is the Accounting Learning Achievement. One of them is the Emotional Quotient. By having a good Emotional Quotient, the students are capable to motivate themselves and avoid them from the bad influences around their social and non-social environment, so they could gain the Accounting Learning Achievement as expected.

Based on the study above, the problems can be drawn to be investigated by taking a research entitled "The Effect of Learning Environment on the Accounting Learning Achievement with Emotional Quotient as Moderating Variable on the Class XI IPS SMA Muhammadiyah 3 Yogyakarta Academic Year 2013/2014.”

\section{RESEARCH METHOD}

\section{Research Type}

The type used in the research is the ex post fact, the researcher tried to define the cause, influence, and the effect of an event which had been studied by the researcher in hindsight. This research is aimed to find the influence of the independent variable, the Learning Environment $\left(\mathrm{X}_{1}\right)$ on the dependent variable, The Accounting Learning Achievement (Y) through moderating variable which strengthen the relation between the independent and dependent variables that is the Emotional Quotient $\left(\mathrm{X}_{2}\right)$. Since the collected data is in numbers, the analysis used is quantitative approach. 


\section{Objective of the Research}

This research has two main objectives. First, it is aimed to investigate the effect of Learning Environment on the Accounting Learning Achievement of XI IPS SMA Muhammadiyah 3 Yogyakarta academic year 2013/2014 students. Second, it is to investigate the influence of Emotional Quotient on the relation between the Learning Environment and Accounting Learning Achievement of XI IPS SMA Muhammadiyah 3 Yogyakarta academic year 2013/2014 students.

\section{Research Instruments}

1. The Instrument's Framework

The instrument's frameworks arranged about the Emotional Quotient and Learning Environment is:

Table 1. The Instrument's Frameworks of Emotional Quotient

\begin{tabular}{|c|l|c|c|}
\hline No & Indicator & Item & Total \\
\hline 1 & $\begin{array}{l}\text { Knowing } \\
\text { self- } \\
\text { emotion }\end{array}$ & $1,2,3,4,5^{*}$ & 5 \\
\hline 2 & $\begin{array}{l}\text { Managing } \\
\text { self- } \\
\text { emotion }\end{array}$ & $6,7,8,9^{*}, 10^{*}$ & 5 \\
\hline 3 & $\begin{array}{l}\text { Self- } \\
\text { motivation }\end{array}$ & $11,12,13,14^{*}, 15^{*}$ & 5 \\
\hline 4 & $\begin{array}{l}\text { Knowing } \\
\text { others' } \\
\text { emotion }\end{array}$ & $16,17,18,19,20^{*}$ & 5 \\
\hline 5 & $\begin{array}{l}\text { Building a } \\
\text { relationship }\end{array}$ & $21,22,23,24,25^{*}$ & 5 \\
\hline \multicolumn{3}{|c|}{ Total Questions } & 25 \\
\hline
\end{tabular}

* The amount of negative statements
Table 2. The Instrument's Frameworks of Learning Environment

\begin{tabular}{|c|c|c|c|}
\hline No & Indicator & Item & Total \\
\hline \multirow[t]{5}{*}{1} & $\begin{array}{c}\text { Social } \\
\text { Surroundings }\end{array}$ & & \\
\hline & a. Parents' role & $\begin{array}{l}1,2,3,4,5 \\
\quad * 6\end{array}$ & 6 \\
\hline & $\begin{array}{l}\text { b. Companion's } \\
\text { role }\end{array}$ & $7,8 *, 9$ & 3 \\
\hline & $\begin{array}{l}\text { c. Classmates' } \\
\text { role }\end{array}$ & $10,11,12$ & 3 \\
\hline & d. Teachers' role & $13,14,15$ & 3 \\
\hline \multirow[t]{5}{*}{2} & $\begin{array}{c}\text { Nonsocial } \\
\text { surroundings }\end{array}$ & & \\
\hline & $\begin{array}{l}\text { a. The learning } \\
\text { spot's } \\
\text { condition }\end{array}$ & $\begin{array}{c}16,17,18 \\
*, 19,20 * \\
, 21\end{array}$ & 6 \\
\hline & $\begin{array}{l}\text { b. The complete } \\
\text { series of } \\
\text { Accounting's } \\
\text { Learning } \\
\text { Tools }\end{array}$ & 22,23 & 2 \\
\hline & $\begin{array}{l}\text { c. The } \\
\text { availability of } \\
\text { Accounting's } \\
\text { Learning } \\
\text { Sources }\end{array}$ & $24,25,26$ & 3 \\
\hline & Total & & 26 \\
\hline
\end{tabular}

*The amount of negative statements

The instruments are modified from Wulan Nugroho Yekti (2011)

The scale used to measure each variable is Likert Scale models which is modified into four multiple choices. Each alternatives score from positive statements (+) and negative statements (-) can be defined as below: 
Table 3. The Alternative Scores of Emotional Quotient's Answers

\begin{tabular}{|c|c|c|c|}
\hline \multicolumn{2}{|c|}{ Positive Statements } & \multicolumn{2}{c|}{ Negative Statements } \\
\hline $\begin{array}{c}\text { Alternative } \\
\text { Answers }\end{array}$ & Score & $\begin{array}{c}\text { Alternative } \\
\text { Scores }\end{array}$ & Score \\
\hline $\begin{array}{c}\text { Totally } \\
\text { Agree (SS) }\end{array}$ & 4 & $\begin{array}{c}\text { Totally } \\
\text { Disagree } \\
\text { (STS) }\end{array}$ & 1 \\
\hline Agree (S) & 3 & $\begin{array}{c}\text { Disagree } \\
\text { (TS) }\end{array}$ & 2 \\
\hline $\begin{array}{c}\text { Disagree } \\
\text { (TS) }\end{array}$ & 2 & Agree (S) & 3 \\
\hline $\begin{array}{c}\text { Totally } \\
\text { Disagree } \\
\text { (STS) }\end{array}$ & 1 & $\begin{array}{c}\text { Totally } \\
\text { Agree (SS) }\end{array}$ & 4 \\
\hline \multicolumn{2}{|c|}{} & \\
\hline
\end{tabular}

Table 4. The Alternative Scores of The Learning Environment's Answers

\begin{tabular}{|c|c|c|c|}
\hline \multicolumn{2}{|c|}{ Positive Statements } & \multicolumn{2}{c|}{ Negative Statements } \\
\hline $\begin{array}{c}\text { Alternative } \\
\text { Answers }\end{array}$ & Score & $\begin{array}{c}\text { Alternative } \\
\text { Answers }\end{array}$ & Score \\
\hline Always & 4 & Never & 1 \\
\hline Often & 3 & Sometimes & 2 \\
\hline Sometimes & 2 & Often & 3 \\
\hline Never & 1 & Always & 4 \\
\hline
\end{tabular}

2. The Instrument's Examination

"A good instrument has these two requirements, being valid and reliable" (Suharsimi, 2006:168). To know the validity and reliability of an instrument, it has to be examined. It is held in the other population, which is similar to the characteristics of class XI IPS SMA Muhammadiyah 3 Yogyakarta students, academic year 2013/2014. Suharsimi Arikunto mentioned that "As a temporary example, for students' analysis unit, the examination's subject can be taken from 25 to 40, as the amount which possible to be held and analyzed" (Suharsimi, 2006:210)

a. Validity Test
Examining the validity of questions is aimed to gain the validity from each question and statements. The validity or the level of validation of an instrument is measured by Karl Pearson's correlation formula of product moment. The formula is defined below:

$$
r_{X Y}=\frac{N \sum X Y-\left(\sum X\right)\left(\sum Y\right)}{\sqrt{\left\{N \sum X^{2}-\left(\sum X\right)^{2}\right\}\left\{N \sum Y^{2}-\left(\sum Y\right)^{2}\right\}}}
$$

Notes:

$$
\begin{aligned}
& r_{x y}: \text { The correlation's co } \\
& \text { efficiency } \\
& \mathrm{N} \text { : The number of } \\
& \text { subjects or } \\
& \text { respondents } \\
& \Sigma \mathrm{X} \quad \text { : The total items } \\
& \Sigma \mathrm{Y} \quad \text { : The total score } \\
& \Sigma X Y \text { : The total } \\
& \text { multiplication of } \mathrm{X} \\
& \text { and } \mathrm{Y} \\
& \left(\Sigma \mathrm{X}^{2}\right) \text { : The total of items' } \\
& \text { squared score } \\
& \left(\Sigma \mathrm{Y}^{2}\right) \text { : The total score of } \\
& \text { squared total } \\
& \text { (Suharsimi, 2009:72). }
\end{aligned}
$$

The instrument's examination in this research is held on 30 students of XII IPS SMA Muhammadiyah 3 Yogyakarta. There are 25 numbers of questionnaire about Emotional Quotient and 26 numbers of questionnaire about Learning Environment. The statements are analyzed by the help of a computer program, SPSS 17 for windows. After $\mathrm{r}_{\mathrm{xy}}$ hitung is found, it is consulted with $r_{\text {tabel }}$ to find the statements' validity. It is valid when $r_{\text {hitung }} \geq r_{\text {tabel }}$ is on $5 \%$ of significance, while it is invalid when $r_{\text {hitung }}<r_{\text {tabel }}$. According to the $\mathrm{r}$ 
Product Moment's value's table (Sugiyono, 2010:373) for $\mathrm{N}=30$ and the significance is in $5 \%$, the value of $r_{\text {tabel }}$ mentioned is 0,361 .

After being consulted with $r_{\text {tabel }}$, there are some fallen statements, it can be explained below:

Table 5. The Summary of Instrument Validity Test

\begin{tabular}{|c|c|c|c|c|}
\hline $\begin{array}{l}\frac{\mathscr{0}}{0} \\
\frac{0}{\frac{\pi}{2}} \\
\frac{\pi}{>}\end{array}$ & 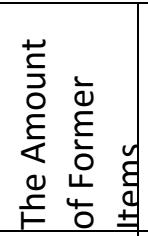 & 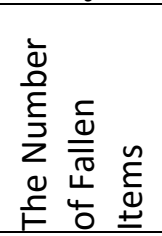 & 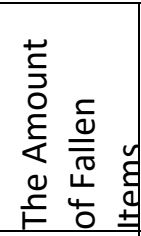 & 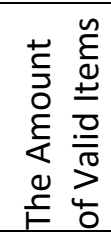 \\
\hline$X_{1}$ & 25 & 9,15 & 2 & 23 \\
\hline$X_{2}$ & 26 & $5,20,25$ & 3 & 23 \\
\hline
\end{tabular}

The result of the validity test showed that the valid items of the questionnaire on Emotional Quotient variable are 23 items and the same valid number mentioned on Learning Environment's questionnaire. These valid items are used as the data collector in this research.

b. Reliability Test

The reliability test is held after the validity test. The instrument is defined as reliable if it is trusted enough to be the data collector, because it is already good and dependable (Suharsimi, 2006:178). The constancy level of a measuring mean in this context is the questionnaire which used the alpha formula:

$$
r_{I I}=\left(\frac{k}{k-1}\right)\left(1-\frac{\sum \sigma_{b}^{2}}{\sigma_{t}^{2}}\right)
$$

Notes:

$$
\begin{aligned}
& r_{\mathrm{II}}= \text { The instrument's } \\
& \text { reliability } \\
& \sum \sigma_{b}^{2}= \text { The amount of items' } \\
& \text { variants } \\
& \sigma_{t}^{2}= \text { The total variants }
\end{aligned}
$$

$$
k=\begin{gathered}
\text { The amount of } \\
\text { questions }
\end{gathered}
$$

Then, the result of $r_{11}$ gained is interpreted through the guide table to give an interpretation on the correlation coefficient. The guide table according to Sugiyono (2010:213) is defined as:

Table 6. The Interpretation's Guide on Correlation's Coefficient

\begin{tabular}{cc|}
$\begin{array}{c}\text { Coefficient's } \\
\text { Interval }\end{array}$ & Interpretation \\
\hline $\mathbf{0 , 0 0}-\mathbf{0 , 1 9 9}$ & Very Low \\
$\mathbf{0 , 2 0}-\mathbf{0 , 3 9 9}$ & Low \\
$\mathbf{0 , 4 0}-\mathbf{0 , 5 9 9}$ & Average \\
$\mathbf{0 , 6 0}-\mathbf{0 , 7 9 9}$ & Strong \\
$\mathbf{0 , 8 0}-\mathbf{1 , 0 0 0}$ & Very Strong \\
\hline
\end{tabular}

An instrument can be defined as reliable if the alpha coefficient is equal or bigger than 0,600 . The reliability test in this research is helped by a computer program, SPSS 17 for windows with the Cronbach Alpha reliability test.

The result of reliability test by using SPSS 17 for Windows has drawn a general conclusion that the instruments of Emotional Quotient and Learning Environment are reliable. The complete result can be seen on the below:

Table 7. The Result of Reliability Test

\begin{tabular}{|l|l|l|l|}
\hline No & $\begin{array}{c}\text { The } \\
\text { Instruments } \\
\text { for } \\
\text { Variables }\end{array}$ & $\begin{array}{c}\text { Alpha } \\
\text { chronbach } \\
\text { coefficient }\end{array}$ & $\begin{array}{c}\text { The } \\
\text { Description } \\
\text { of } \\
\text { Reliability }\end{array}$ \\
\hline 1. & $\begin{array}{l}\text { The } \\
\text { Emotional } \\
\text { Quotient } \\
\left(\mathrm{X}_{1}\right)\end{array}$ & 0.886 & Very Strong \\
\hline 2. & $\begin{array}{l}\text { The } \\
\text { Learning } \\
\text { Environment } \\
\left(\mathrm{X}_{2}\right)\end{array}$ & 0.883 & Very Strong \\
\hline
\end{tabular}




$\begin{array}{lll}\text { RESEARCH } & \text { RESULT } & \text { AND } \\ \text { DISCUSSION } & \end{array}$

1. The Effect of Learning Environment on The Accounting Learning Achievement in XI IPS SMA Muhammadiyah 3 Yogyakarta Academic Year 2013/2014

The analysis findings show that the value of t-count between the learning environment and the achievement on The Accounting Learning process in XI IPS Class of SMA Muhammadiyah 3 Yogyakarta Academic Year 2013/2014 can be explained in the table below:

Table 8. The Summary of Learning Environment $t$ Test on Learning Achievement

\begin{tabular}{|l|r|r|r|r|r|c|}
\hline Source & $\begin{array}{c}\text { Koe } \\
\text { f }\end{array}$ & $r_{x l y}$ & $\begin{array}{c}r_{x l}^{2} \\
y\end{array}$ & $T$ & $P$ & Note \\
\hline Constants & $\begin{array}{r}23 . \\
301\end{array}$ & & & & & \\
\hline $\begin{array}{l}\text { Learning } \\
\text { Environme } \\
\text { nt }\end{array}$ & $\begin{array}{r}0.5 \\
90\end{array}$ & 0.2 & 0.0 & 2.9 & 0.0 & $\begin{array}{c}\text { Signi } \\
\text { fican } \\
\mathrm{t}\end{array}$ \\
\hline
\end{tabular}

Source: The Processed Primary Data, 2014.

From 0.590 as the coefficient predicator and 23.302 as the constant number above, it can be arranged that the regression line of one predictor equation is $Y=23.301+0.590 X_{1}$. It means that the equation shows that the regression coefficient is positive for 0.590 which also implies that the Accounting Learning Environment (Y) increased to 0.590 when the Learning Environment $\left(\mathrm{X}_{1}\right)$ increased to 1 .

The findings from the simple regression analysis with one predictor show that the correlation coefficient $\left(\mathrm{r}_{\mathrm{x} 1 \mathrm{y}}\right)$ is 0.277 . The data show the summary of the first positive hypotheses study findings. Thus, the Learning Environment positively influenced the Achievement Accounting Learning Environment in XI IPS Class of SMA
Muhammadiyah 3 Yogyakarta Academic Year 2013/2014.

According to the analysis of data findings, it is gained that the t-count value is 2.917 , while the significant value is 0.004 < Level of Significant $=0.05$ or $\mathrm{t}$-count $=2.917>\mathrm{t}$-table $=1.980$. It means that there is a positive and significant influence from the learning environment variable on the Accounting Learning Achievement in XI IPS Class SMA Muhammadiyah 3 Yogyakarta Academic Year 2013/2014.

It is stated that the determinant coefficient $r_{x 1 y}^{2}$ is 0.077 . Thus, it showed that the learning environment is able to be $7.7 \%$ influential of the change of the Accounting Learning Achievement. It also shows that there is $92.3 \%$ factor or the other variables which is possibly influential to the Accounting Learning Achievement.

According to the calculation above, the first hypotheses which stated that "The Learning Environment is Positively Influential to The Accounting Learning Achievement in XI IPS Class of SMA Muhammadiyah 3 Yogyakarta Academic Year 2013/2014" is accepted.

2. The Effect of Emotional Quotient on The Relationship Between Learning Environment and Accounting Learning Achievement in XI IPS SMA Muhammadiyah 3 Yogyakarta Academic Year 2013/2014

The analysis findings which show that the value of t-count between the learning environment as moderating variable and the emotional quotient variable on the achievement of the Accounting learning process in XI IPS Class SMA Muhammadiyah 3 Yogyakarta Academic Year 2013/2014 is explained below: 
Table 9. The Summary of Learning Environment Variable t Test and Emotional Quotient on Learning Achievement

\begin{tabular}{|c|c|c|c|c|c|c|}
\hline Source & Koef & $r_{x 2 y}$ & $r_{x 2 y}^{2}$ & $t$ & $P$ & Note \\
\hline $\begin{array}{l}\text { Cons- } \\
\text { tants }\end{array}$ & 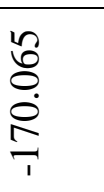 & & & & & \\
\hline $\begin{array}{l}\text { Emotio- } \\
\text { nal Quo- } \\
\text { tient on } \\
\text { Lear- } \\
\text { ning } \\
\text { Envi- } \\
\text { ronment }\end{array}$ & $\begin{array}{l}\text { n̊ } \\
\text { nุ }\end{array}$ & ָิ & $\frac{t}{0}$ & $\begin{array}{l}0 \\
\infty \\
0 \\
\text { i }\end{array}$ & $\stackrel{8}{8}$ & 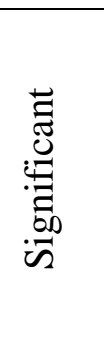 \\
\hline
\end{tabular}

Source: The Processed Primary Data, 2014.

According to the findings of the Proceed data, it gained that the value of $t-$ count is 2.686 and the significance value $=0.003<$ Level of Significant $=0,005$ to $\mathrm{t}$-count $=2.686$. $\mathrm{T}$-table $=1.980$. It is implied that there is a positive and significant influence from the learning environment as moderating variable and the emotional quotient on the Accounting Learning Achievement in XI IPS Class of SMA Muhammadiyah 3 Yogyakarta Academic Year 2013/2014.

The regression findings show that $\mathrm{R}^{2}$ (Determination Coefficient or $R$ Square) is 0.164. It means that the dependent variable $(\mathrm{Y})$ in the model is the Accounting Learning Enviroment in XI IPS Class of SMA Muhammadiyah 3 Yogyakarta Academic Year 2013/2014 which is explained by the independent variable $(\mathrm{X})$ is the learning environment variable (X1), and emotional quotient as moderating variable (X2) in which the value is $16.4 \%$. The rest $83.6 \%$ is explained by the other variables which are the non model.

According to the measurement above, the second hypotheses which stated that "The Emotional Quotient is Positively Influential to the Relation between The Learning Environment and The Accounting Learning Achievement in XI IPS Class of SMA Muhammadiyah 3 Yogyakarta Academic Year 2013/2014" is accepted.

\section{CONCLUSION}

The analysis findings showed that the value of t-count is 2.917 and the significance value $=0.004<$ Level of Significant $=0.05$ or $\mathrm{t}$-count $=2.917>\mathrm{t}$ table $=1.980$. It means that there is a positive and significant influence from the learning environment on the variable of The Accounting Learning Achievement in XI IPS Class of SMA Muhammadiyah 3 Yogyakarta Academic Year 2013/2014.

The analysis findings showed that the value of t-count is 2.686 and the significance value $=0.003<$ Level of Significant $=0.05$ or $\mathrm{t}$-count $=2.686>\mathrm{t}$ table $=1.980$. It means that there is an influence of Emotional Quotient on The Relation between The Learning Environment and The Accounting Learning Achievement in XI IPS Class of SMA Muhammadiyah 3 Yogyakarta Academic Year 2013/2014.

\section{REFERENCES}

Ary Ginanjar Agustian. (2009). Emosional Spiritual Quotient. Jakarta: Arga Wijaya Persada.

Bimo Walgito. (2010). Bimbingan Konseling (Studie Karier). Yogyakarta: Andi Offset.

Dalyono, M. (2001). Psikologi Pendidikan. Jakarta: Rineka Cipta.

Dwi Siswoyo. (2007). Ilmu Pendidikan. Yogyakarta: UNY Press.

Ghozali, Imam. (2001). Aplikasi Analisis Multivariate Dengan Program SPSS.Semarang: Badan Penerbit Universitas Diponegoro. 
Goleman, Daniel. (2000). Kecerdasan Emosi untuk Mencapai Puncak Prestasi. Jakarta: Gramedia Pustaka Utama.

Hamzah Uno, dkk. (2006). Perencanaan Pembelajaran. Jakarta: Alawiyah Press.

Haryono Yusuf. (2001). Dasar-Dasar Akuntansi. Yogyakarta: STIE YKPN.

Ismani dkk. (2010). Pedoman Penulisan Tugas Akhir. Yogyakarta: Jurusan Pendidikan Akuntansi UNY.

Muhibbin Syah. (2005). Psikologi Pendidikan dengan Pendekatan Baru. Bandung: Rosda Karya.

Nana Syaodih Sukmadinata. (2004). Landasan Psikologi Proses Pendidikan. Bandung: Remaja Rosda Karya.

Ngalim Purwanto. (2004). Psikologi Pendidikan. Bandung: PT Remaja Rosdakarya.

Oemar Hamalik. (2003). Proses Belajar Mengajar. Bandung: Sinar Baru. PT. Bumi Aksara. 